\title{
PENGARUH PUPUK ORGANIK TERHADAP PRODUKSI DAN KUALITAS HIJAUAN PASTURA CAMPURAN PADA LAHAN KERING DI DESA SEBUDI KARANGASEM.
}

\author{
SUARNA, I W., DAN I K. M. BUDIASA \\ Fakultas Peternakan Universitas Udayana Denpasar-Bali \\ e-mail: suarnawyn@yahoo.com
}

\begin{abstract}
ABSTRAK
Meningkatkan luasan tutupan vegetasi adalah salah satu upaya untuk berperan serta dalam meningkatkan penyerapan gas rumah kaca yang menjadi pemicu munculnya perubahan iklim. Terkait hal tersebut tumbuhan pakan memiliki peran yang sangat strategis karena selain dapat menyediakan hijauan pakan juga dapat meningkatkan tutupan vegetasi dengan memanfaatkan lahan kering dan bahkan lahan kritis untuk penanaman tumbuhan pakan. Meningkatnya pemberian pupuk kandang sapi dan pupuk bioslury dapat meningkatkan produksi dan kualitas hijauan total rumput panikum atau paspalum yang ditanam bersama legume. Berat kering oven total hijauan rumput paspalum yang ditanam bersama rumput panikum dan legume Centrocema yang dipupuk dengan pupuk kandang sapi yakni masing-masing sebesar 4,75 dan 4,36 t ha-1. Penggunaan pupuk organik akan menghasilkan kualitas hijauan yang semakin baik apabila diterapkan pada kombinasi penanaman rumput panikum, paspalum dan leguminosa.
\end{abstract}

Kata kunci: pasture campuran, pupuk organik, produksi dan kualitas hijauan, lahan kering

\section{ORGANIC FERTILIZER IMPLEMENTATION FOR MIXED PASTURE PRODUCTION AND QUALITY ON DRYLAND AT SEBUDI KARANGASEM}

\begin{abstract}
The increase of vegetation coverage is one of the efforts to improve greenhouse gases absorption that trigger the emergence of climate change. This is related to forage strategic role in providing forage production and increase vegetation coverage to improve dryland condition. Compost and fertilizer bioslury provision to vegetation can increase forage production and quality of panikum or paspalum grasses planted within legume. Total dry weight of forage of paspalum grass planted within panikum grass, legume centrocema and compost, respectively at 4.75 and $4.36 \mathrm{t} \mathrm{ha}^{-1}$. The use of organic fertilizer will produce better quality forage when applied within the combination of panicum, paspalum and legume.
\end{abstract}

Keywords: mixed pasture, organic fertilizers, production and forage quality, dryland

\section{PENDAHULUAN}

Bali memiliki berbagai jenis ternak pemakan hijauan (ruminansia) yang sangat terkenal dan telah dijadikan komuditas unggulan. Sapi bali sebagai salah satu komuditas unggulan Provinsi Bali juga menjadi salah satu fokus riset sesuai Rencana Induk Pengembangan (RIP) dalam bidang riset di Universitas Udayana. Salah satu permasalahan dominan yang dihadapi peternak sapi di Bali adalah semakin menurunnya ketersediaan hijauan pakan yang berkualitas. Peningkatan jumlah hijauan pakan membawa konsekuensi dan keharusan membudidayakan tumbuhan pakan, meningkatkan tutupan vegetasi, dan meningkatkan akumulasi karbon padatumbuhan(As-syakur etal.2011). Dengan demikian budidaya tanaman pakan juga merupakan upaya strategis untuk mempertahankan dan meningkatkan produksi ternak sekaligus melakukan upaya konservasi terhadap lahan kritis dan mitigasi terhadap perubahan iklim.

Perubahan iklim telah menjadi isu lingkungan global yang akan mengakibatkan munculnya berbagai bencana lingkungan. Deklarasi Bali telah mewajibkan dunia untuk melakukan upaya mitigasi, adaptasi, dan transfer teknologi untuk menanggulangi dampak perubahan iklim. Meningkatkan luasan tutupan vegetasi adalah salah satu upaya untuk berperan serta dalam meningkatkan penyerapan gas rumah kaca (GRK) yang menjadi pemicu munculnya perubahan iklim. Terkait hal tersebut saat ini tumbuhan pakan memiliki peran 
yang sangat strategis karena selain dapat meningkatkan ketersediaan hijauan pakan juga merupakan aktivitas mitigasi perubahan iklim yang efektif (Suarna, 2011). Kondisi tersebut didukung oleh program Pemerintah Daerah Bali (Simantri) dan Pemerintah Pusat (Tujuan Pembangunan Milineum) dan upaya untuk lebih meningkatkan potensi lokal sebagai pendukung utama pembangunan peternakan.

Berdasarkan hal tersebut sangat diperlukan sebuah penelitian yang bertujuan untuk untuk mendapatkan pengaruh pupuk organik terhadap produksi dan kualitas hijauan pasura campuran pada lahan kering di Desa Sebudi Karangasem.

\section{MATERI DAN METODE}

Percobaan lapangan dilaksanakan pada lahan kering di Banjar Sogra, Desa Sebudi, Karangasem dari bulan April sampai September 2015. Percobaan menggunakan rancangan acak kelompok dengan 12 perlakuan dan diulang tiga kali. Rancangan perlakuan disusun sebagai berikut:

1. Kombinasi rumput panikum + centrosema $+1,5$ kg pupuk kandang sapi

2. Kombinasi rumput panikum + centrosema $+3 \mathrm{~kg}$ pupuk kandang sapi

3. Kombinasi rumput panikum + Clitoria $+9 \mathrm{~kg}$ bioslury

4. Kombinasi rumput panikum + Clitoria $+18 \mathrm{~kg}$ bioslury

5. Kombinasi rumput Paspalum + Centrocema $+1,5$ kg pupuk kandang sapi

6. Kombinasi rumput Paspalum + Centrocema +3 kg pupuk kandang sapi

7. Kombinasi rumput Paspalum + Clitoria $+9 \mathrm{~kg}$ bioslury

8. Kombinasi rumput Paspalum + Clitoria $+18 \mathrm{~kg}$ bioslury

9. Kombinasi rumput Paspalum+ Panikum + Centrocema $+1,5 \mathrm{~kg}$ pupuk kandang sapi

10. Kombinasi rumput Paspalum + Panikum + Centrocema $+3 \mathrm{~kg}$ pupuk kandang sapi

11. Kombinasi rumput Paspalum + Panikum + Clitoria $+9 \mathrm{~kg}$ bioslury

12. Kombinasi rumput Paspalum + Panikum + Clitoria $+18 \mathrm{~kg}$ bioslury

Variabel yang diamati antara lain adalah berat kering oven akar, batang, dan daun tanaman serta kualitas hijauan dilihat dari komposisi kimia hijauannya seperti abu, bahan organik, serat kasar dan protein kasar.

Bahan-bahan yang dipergunakan dalam percobaan ini antara lain adalah:

1. Biji rumput (Paspalum atratum dan Panicum maksimum) dan legum (Clitoria ternatea dan
Centrocema pubescens) yang ditanam dalam pola asosiasi,

2. Berbagai reagen diperlukan untuk analisis komposisi kimia (analisis Proksimat)

3.Pupuk organik (pupuk kandang dan pupuk bioslurry)

Alat yang digunakan dalam percobaan ini, antara adalah:

1. Soil-pH dan Humidity Tester, Model DM-5. Takemura Electric Works, LTD. Tokyo Japan.

2. Portable Leaf Area Meter, LAW-A. Beijing KWF Sci-Tech Development Co., Ltd.

3. Timbangan yang berkapasitas $22.6 \mathrm{~kg}$ dengan ketelitian $10 \mathrm{~g}$, yang digunakan untuk menimbang berat hijauan segar;

4.Timbangan Mettler Toledo PB 3002 buatan Switzerland, berkapasitas $500 \mathrm{~g}$ dengan ketelitian o.01 mg, diperlukan untuk menimbang sampel untuk keperluan analisis kimia.

5. Oven pengering buatan Australia PVY. Ltd. model GC-2, untuk mengeringkan sampel hijauan.

6.Hammer mill untuk menggiling sampel. Penggilingan elektronik dengan diameter lubang $0.1 \mathrm{~mm}$, preparasi sampel untuk analisis kimia.

\section{Analisis Data}

Data yang diperoleh terhadap semua variabel yang diukur dianalisis dengan sidik ragam univariat (Steel dan Torrie, 1989) dan ditampilkan dalam bentuk tabel. Apabila analisis sidik ragam menunjukkan perbedaan yang nyata, maka perbedaan nilai rata-rata perlakuan selanjutnya diuji dengan mempergunakan uji jarak berganda Duncan (Gomez dan Gomez, 1995).

\section{HASIL DAN PEMBAHASAN}

Kegiatan penelitian diawali dengan melaksanakan skoping. Skoping dilakukan sebanyak dua kali karena ada kesulitan didalam memilih lokasi, terutama berkaitan dengan kesediaan masyarakat untuk menyewakan lahannya dan lokasi kawasan yang terkadang sulit dijangkau. Skoping dilakukan pada tanggal 5 dan 19 Maret 2015 untuk mendapatkan lokasi penelitian yang sesuai dengan rencana riset.

Curah hujan rata-rata bulanan selama 10 tahun dari Stasiun pengamat curah hujan pada BPP Kecamatan Selat sebesar $3.628 \mathrm{~mm} \mathrm{th}^{-1}$ dengan 123 hari hujan. Curah hujan terendah pada bulan Agustus sebesar $160 \mathrm{~mm}$ bulan $^{-1}$ dengan 6 hari hujan dan tertinggi pada bulan Desember sebesar $419 \mathrm{~mm}_{\text {bulan }}^{-1}$ dengan 12 hari hujan. Curah hujan ini mempengaruhi daerah penelitian pada sebagian wilayah di Desa Sebudi.

Tipe iklim diperoleh dengan rasio antara jumlah rerata bulan kering dengan jumlah bulan basah dari 
masing-masing stasiun penakar curah hujan. Dari hasil perhitungan diperoleh nilai $\mathrm{Q}$ berada diantara $\mathrm{O}<\mathrm{Q}<0,143$ artinya tipe iklim menurut Schmidht Ferguson pada kawasan Sub DAS Telagawaja termasuk tipe iklim A (sangat basah). Namun pada tahun 2014 iklim telah mengalami perubahan dimana hujan turun mulai akhir bulan November. Sedangkan pada tahun 2015 ketika penelitian dilakukan bulan kering lebih panjang dari pada bulan basah.

Hasil penelitian menunjukkan bahwa berat kering akar tertinggi dijumpai pada pastura campuran rumput panikum dan paspalum yang dipupuk dengan bioslurry sebanyak $9 \mathrm{~kg}$ (A12). tetapi berat kering daunnya paling rendah yakni $39,5 \mathrm{~g}$ per $\mathrm{m}^{2}$. Perlakuan A9 dan A10 memberikan produksi hijauan (batang dan daun) yang lebih tinggi daripada perlakuan lainnya. Tingginya produksi tersebut disebabkan oleh adanya pemberian pupuk pupuk kandang sapi yang mampu menyediakan kondisi yang baik bagi perkembangan jazad mikro dan makro tanah. Pupuk kandang sapi yang digunakan adalah pupuk yang sudah matang dan hampir menyerupai tanah sehingga pelepasan hara dari pupuk tersebut akan lebih cepat terjadi dibandingkan dengan menggunakan pupuk bioslurry.

Tabel 1. Berat kering oven akar, batang, dan daun tanaman

\begin{tabular}{cccccc}
\hline Perlakuan & Akar & Batang & \multicolumn{1}{l}{ Daun } \\
& $\ldots \ldots \ldots \ldots . . . \mathrm{g} \mathrm{m}^{-2}$ & $\ldots \ldots \ldots .$. & \\
\hline A1 & 23,90 & $\mathrm{c}$ & $11,94 \mathrm{c}$ & $2,70 \mathrm{e}$ \\
A2 & $27,25 \mathrm{c}$ & $19,40 \mathrm{c}$ & $9,00 \mathrm{e}$ \\
A3 & $34,65 \mathrm{c}$ & $11,55 \mathrm{c}$ & $6,80 \mathrm{e}$ \\
A4 & $22,35 \mathrm{c}$ & $18,20 \mathrm{c}$ & $9,50 \mathrm{e}$ \\
A5 & $55,03 \mathrm{~b}$ & $13,20 \mathrm{c}$ & $24,35 \mathrm{c}$ \\
A6 & $66,65 \mathrm{ab}$ & $33,65 \mathrm{bc}$ & $33,90 \mathrm{bc}$ \\
A7 & $53,25 \mathrm{~b}$ & $78,85 \mathrm{a}$ & $48,70 \mathrm{ab}$ \\
A8 & $79,95 \mathrm{a}$ & $35,05 \mathrm{~b}$ & $43,50 \mathrm{~b}$ \\
A9 & $73,25 \mathrm{ab}$ & $49,60 \mathrm{ab}$ & $69,10 \mathrm{a}$ \\
A10 & $81,40 \mathrm{a}$ & $56,35 \mathrm{a}$ & $52,70 \mathrm{a}$ \\
A11 & $60,80 \mathrm{ab}$ & $22,90 \mathrm{bc}$ & $17,35 \mathrm{~d}$ \\
A12 & $88,30 \mathrm{a}$ & $50,60 \mathrm{a}$ & $39,50 \mathrm{~b}$ \\
\hline
\end{tabular}

Peningkatan pemberian pupuk kandang sapi dan atau pupuk bioslurry dapat memberikan hasil hijauan yang lebih tinggi pada pasture campuran legum dengan panikum, legum dengan paspalum, dan pasture campuran legum dengan panikum dan paspalum. Legum clitoria memberikan hasil hijauan yang lebih tinggi apabila ditanam bersama panikum atau paspalum, tetapi produksi hijauan klitoria akan menurun bila ditanam bersama panikum dan paspalum. Tanaman legum memberikan kontribusi hara kepada tanaman rumput yang hidup berdampingan dengan legume. Hal tersebut diungkapkan oleh Alison (1994) dan Herryawan (2013). Hal sebaliknya terjadi pada centrocema yang memberikan hasil lebih tinggi pada pasture campuran bersama panikum dan paspalum. Hal tersebut sangat dimungkinkan oleh karena sifat tumbuh tanaman berbeda dan clitoria membutuhkan sinar matahari yang lebih banyak, centrocema lebih tahan terhadap naungan dibandingkan dengan clitoria. Fenomena tersebut sesuai dengan hasil penelitian Suarna et al. (2014 ${ }^{\mathrm{a}}$ )

Berat kering oven total hijauan rumput paspalum yang ditanam bersama rumput panikum dan legume Centrocema yang dipupuk dengan pupuk kandang sapi (A9 dan A10) lebih tinggi dari pada perlakuan lainnya yakni masing-masing sebesar 4,75 dan 4,36 t ha-1. Sedangkan berat kering oven total hijauan paspalum yang ditanam bersama legume clitoria yang dipupuk dengan bioslury adalah tertinggi yakni sebesar $5,1 \mathrm{t} \mathrm{ha}^{-1}$. Hal tersebut sesuai dengan hasil analisis terhadap volume dan kerapatan tanaman yang menunjukkan hasil tertinggi pada asosiasi rumput paspalum dengan legum clitoria (Suarna et al. $\left(2014^{\mathrm{b}}\right)$.

Berdasarkan Tabel 1 dapat dinyatakan bahwa penanaman legum akan dapat meningkatkan pertumbuhan dan hasil tanaman rumput. Rumput paspalum memberikan respons pertumbuhan dan produksi yang lebih baik dari pada rumput panikum. Rumput panikum yang ditanam bersama paspalum dan legum clitoria atau centrosema memberikan produksi hijauan yang lebih baik dari pada ditanam bersama legume saja.

Kualitas hijauan dapat dilihat dari komposisi kimia hijauan pada masing-masing perlakuan. Pada Tabel 2 dapat dilihat bahwa rumput panikum atau paspalum yang ditanam bersama clitoria memberikan bahan organik yang lebih tinggi dibandingkan ditanam bersama centrocema. Kandungan protein hijauan lebih tinggi pada rumput yang ditanam bersama centrocema dibandingkan ditanam bersama clitoria. Meningkatnya pemberian pupuk pupuk kandang sapi dan pupuk bioslury dapat meningkatkan produksi dan kualitas hijauan total rumput panikum atau paspalum yang ditanam bersama legum (Usha et al., 2010; Miller, 1984; dan Skerman, 1977). Penggunaan pupuk organik akan menghasilkan kualitas hijauan yang semakin baik apabila diterapkan pada kombinasi penanaman rumput panikum, paspalum dan leguminosa.

\section{SIMPULAN}

Berdasarkan hasil penelitian di atas dapat disimpulkan bahwa meningkatnya pemberian pupuk kandang sapi dan pupuk bioslury dapat meningkatkan produksi dan kualitas hijauan total rumput panikum atau paspalum yang ditanam bersama legume. Berat kering oven total hijauan rumput paspalum yang ditanam bersama rumput panikum dan legum centrocema yang dipupuk dengan pupuk kandang sapi yakni masing-masing sebesar 4,75 dan 4,36 t ha-1 . 
Tabel 2. Komposisi kimia hijauan rumput Panikum dan Paspalum yang ditanam di lahan kering Banjar Sogra, Desa Sebudi, Kabupaten Karangasem.

\begin{tabular}{|c|c|c|c|c|c|}
\hline \multirow[t]{2}{*}{ Perlakuan } & DM & $A B U$ & BO & SK & PK \\
\hline & \multicolumn{5}{|c|}{$\ldots \ldots \ldots \ldots . . \mathrm{g} \mathrm{m}^{-2} \ldots \ldots \ldots \ldots$} \\
\hline $\mathrm{A} 1$ & $68,12 \mathrm{~b}$ & $8,55 b$ & 61,07 a & $22,76 \mathrm{~b}$ & $22,76 \mathrm{~b}$ \\
\hline A2 & $65,27 b$ & $8,35 b$ & 58,42 a & $22,09 b$ & 9,79 a \\
\hline $\mathrm{A} 3$ & $59,91 \mathrm{~b}$ & $7,29 \mathrm{~b}$ & $54,13 \mathrm{a}$ & $19,39 \mathrm{~b}$ & $8,07 \mathrm{~b}$ \\
\hline A4 & $95,40 \mathrm{a}$ & $12,09 \mathrm{a}$ & 84,82 a & $31,76 \mathrm{a}$ & $13,14 \mathrm{a}$ \\
\hline A5 & $66,39 \mathrm{~b}$ & $8,87 \mathrm{~b}$ & 59,01 a & $18,54 \mathrm{~b}$ & $14,69 \mathrm{a}$ \\
\hline A6 & $55,09 \mathrm{~b}$ & $7,23 \mathrm{~b}$ & 49,37 a & $15,98 \mathrm{~b}$ & 9,91 a \\
\hline A7 & $85,56 a b$ & $10,91 \mathrm{ab}$ & 76,15 a & 24,74 a & 6,04 a \\
\hline A8 & 96,40 a & 13,40 a & 84,49 a & $28,74 \mathrm{a}$ & 9,99 a \\
\hline A9 & $64,79 b$ & $8,55 b$ & 57,73 a & $19,07 \mathrm{~b}$ & 6,91 a \\
\hline A10 & $52,85 \mathrm{~b}$ & $7,40 \mathrm{~b}$ & 46,95 a & $16,08 \mathrm{~b}$ & $16,08 \mathrm{~b}$ \\
\hline A11 & $67,29 \mathrm{~b}$ & $8,73 \mathrm{~b}$ & 60,06 a & $19,69 \mathrm{~b}$ & $19,69 \mathrm{~b}$ \\
\hline A12 & $49,81 \mathrm{~b}$ & $6,40 \mathrm{~b}$ & 44,90 a & $14,42 \mathrm{~b}$ & $14,42 b$ \\
\hline
\end{tabular}

Penggunaan pupuk organik akan menghasilkan kualitas hijauan yang semakin baik apabila diterapkan pada kombinasi penanaman rumput panikum, paspalum dan leguminosa.

\section{DAFTAR PUSTAKA}

Alison, M.W. and W.D. Pitman. 1995. Legume use in pastures. Louisiana Agric. 38:16-17.

As-syakur, A.R. I.W. Suarna, I.W. Rusna, I.N. Dibia. 2011. Pemetaan kesesuaian iklim tanaman pakan serta kerentanannya terhadap perubahan iklim dengan sistem informasi geografi (SIG) di Provinsi Bali. Jurnal Pastura, 1:1 (9-15).

Gomez, K.A dan A.A. Gomez. 1995. Prosedur Statistik Untuk Penelitian Pertanian. Terjemahan E.Sjamsuddin dan J. S. Baharsjah. UI-Press. Jakarta, halaman 87-219.

Herryawan K.M. 2013. Mekanisme transfer nutrisi dari legum ke rumput yang diinokulasi FMA (Ifapet). Proc
Seminar Tumbuhan Pakan HITPI, 28 Juni 2013 di Hotel Inna Bali, Denpasar. Halaman 118-131

Miller, D.A. 1984. Forages crops. Mc Graw-Hill. Inc. New York, p. 53-6o.

Sheoran, V., A. S. Sheoran, P. Poonia. 2010. Soil reclamation of abandoned mine land by revegetation: A Review. International Journal of Soil, Sediment and Water, Vol 3 No.2

Skerman, P.J. 1977. Tropical forage legume. FAO. Rome, p. 69-89.

Steel, R.G. D. and J.H. Torrie. 1989. Prinsip dan Prosedur Statistika: Suatu Pendekatan Biometrik. Alih bahasa: Bambang Sumantri. Edisi kedua. PT. Gramedia. Jakarta, halaman 148-190.

Suarna, I W. 2011. Peran tanaman pakan dalam mitigasi dan adaptasi terhadap perubahan iklim. Prosiding, Semiloka Nasional Himpunan Ilmuwan Tanaman Pakan Indonesia (HITPI), 5 Nopember 2010 di Universitas Udayana

Suarna, W., N.N. Candraasih K., dan M.A.P. Duarsa. 2014. Model asosiasi tanaman pakan adaptif untuk perbaikan lahan pasca tambang di Kabupaten Karangasem. J. Bumi Lestari. 4 (1): 9-14.

Suarna, W., N.N. Candraasih K., A.A.A.S. Trisnadewi, dan M.A.P. Duarsa. 2014. Produktivitas rumput panikum dan paspalum dalam kombinasinya dengan legum pada lahan kering. Prosiding Semnas III HITPI di Bukit Tinggi. 211-216

Usha P. Pillai-McGarryA, Craig Lockhart B. and David Mulligan. 2010. Soil factors affecting vegetation establishment after sand mining on North Stradbroke Island.19th World Congress of Soil Science, Soil Solutions for a Changing World $1-6$ August 2010, Brisbane, Australia. Published on DVD.

Van Soest, P.J. 1985. Composition, Fiber Quality, And Nutritive Value Of Forages. p. 412-421. In H.E. Heath, R.F. Barnes, and D.S. Metcalfe (ed.) Forages. Iowa State University Press. Ames, Iowa. 